\title{
OBSERVATIONS ON THE URINE OF THE NEW-BORN INFANT
}

\author{
BY \\ JOHN THOMSON, M.D., D.P.H., D.C.H. \\ Crichton Research Scholar \\ (From the Department of Child Life and Health, University of Edinburgh)
}

Publications dealing with the physical and chemical characteristics of the urine in the new-born period date from 1864: They are most common in the German literature of last century. In some instances the observations are incomplete while in others they are obviously inaccurate. In general, these shortcomings arise from the difficulty of collecting the specimens of urine. Many ingenious methods of collecting urine from infants and young children are on record and a close search of the literature reveals over forty references to the subject. The apparatus in use in the present investigation consists of two parts, the one a urinal and the other an electrical signalling device.

\section{Apparatus}

The urinal is made from the following materials:

(1) A rubber pear-shaped ear syringe

(2) A white collar stud

(3) A piece of rubber tubing

(4) A collecting vessel with a two-holed rubber stopper

(5) A pair of rubber straps about 11 inches long by $\frac{3}{4}$ inch broad

These can be cut from a disused motor-car inner tube

(6) Safety pins

Fig. 1, 2 and 3 show the construction and method of application of the urinal. The aperture in the side of the syringe is not more than $1 \frac{1}{4}$ inches in diameter. The collar stud passes through the wall of the syringe from within outwards and directly opposite the aperture. It then passes through the centre of each of the rubber straps in turn. It is essential to fit the appliance carefully. For this purpose it is necessary to have about six syringes available. Each syringe has a slightly different size of aperture. In the case of the male infant the scrotum and penis are slipped inside the syringe while in the case of the female infant the aperture in the syringe encloses the labia majora. It is necessary to pin the rubber straps up with sufficient tension to prevent the syringe from falling away from the external genitalia. Care must also be taken not to pull the syringe backwards over the anus. A rubber tube is attached to the exit from the syringe and leads to a collecting vessel. A test-tube, held vertically in a retort stand at the cot side, is satisfactory.

The electrical signalling device consists of a glass float chamber and an ebonite stopper which carries two electrical terminals. The method of construction and operation are clearly shown in fig. 4 . The electrical circuit closes when the float rises, and opens when the float chamber is drained.

\section{The daily volume of urine}

It is recognized that the daily volume of urine which the infant passes during the first days of life varies greatly and that there is a considerable variation from infant to infant. Fig. 5 illustrates

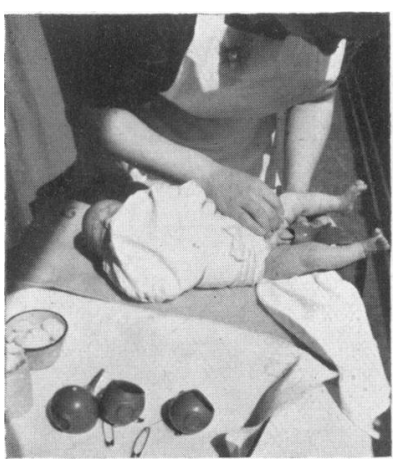

FIG. 1.-Selecting a syringe of a suitable size.

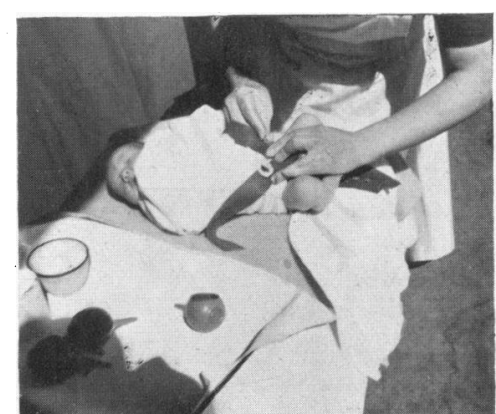

Fig. 2.-Fastening the anterior ends of the rubber straps. 169

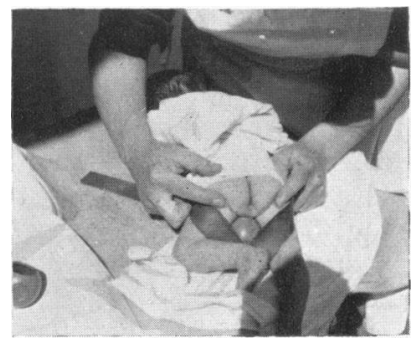

FIG. 3.-To show clearance from the anus. 


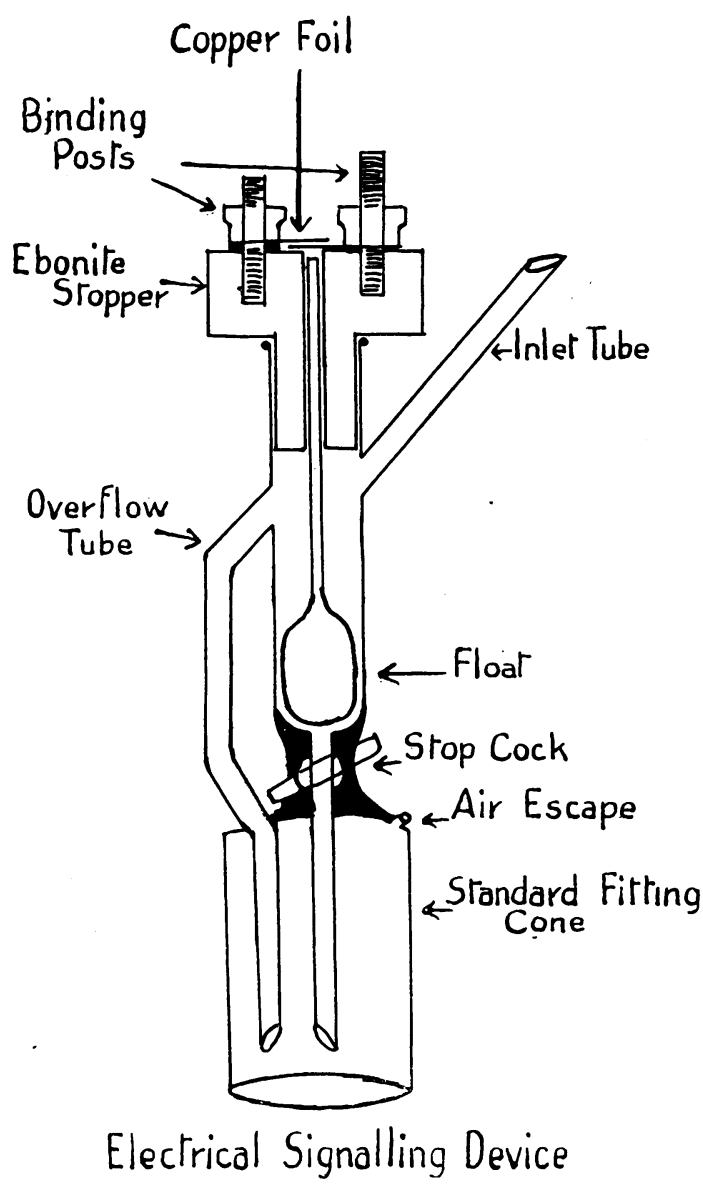

FIG. 4. the average daily amount which is passed by the new-born infant. It shows, as might be expected, a steady increase from day to day. This is in sharp contrast to the findings of Martin and Ruge (1876), and Hofmeier (1882). In both these cases the figures given are almost certainly inaccurate from the fourth day onwards. The publications of Cruse (1877) and Camerer (1896) record figures considerably greater than those now published. It is clear that this is due to abnormally large intakes of fluid for Cruse states that the infants were foundlings and that they were put to the breast of wet nurses who had already been lactating for an average period of four-and-a-half months. Though no information is given on this point, a similar explanation probably accounts for the high figures of Schloss and Crawford (1911). The graph now published approximates to that which represents the observations of Reusing (1895), while at its beginning and termination it shows a certain similarity to that representing the work of Schiff (1893). Unfortunately, Schiff gives no information concerning the daily volume of the intake.

Whilst the graph illustrates a steady rise in the average daily volume of the urine, table 1 shows a wide range within which the daily volume of the urine may vary. These daily variations are well illustrated by the following three cases.
Average Daily Volume of Urine 
TABLE 2

AVERAGE DAILY INTAKE AND OUTPUT

\begin{tabular}{|c|c|c|c|c|}
\hline Day & $\begin{array}{l}\text { Number } \\
\text { of infants }\end{array}$ & $\begin{array}{l}\text { Milk, } \\
\text { c.c. }\end{array}$ & $\begin{array}{l}\text { Urine, } \\
\text { c.c. }\end{array}$ & $\begin{array}{l}\text { Per cent. } \\
\text { of intake } \\
\text { returned } \\
\text { as output }\end{array}$ \\
\hline $\begin{aligned} 1 & . \\
2 & . . \\
3 & . . \\
4 & . \\
5 & . \\
6 & . \\
7 & . \\
8 & . \\
9 & . \\
10 & . \\
11 & . \\
12 & .\end{aligned}$ & $\begin{array}{r}27 \\
26 \\
26 \\
25 \\
23 \\
20 \\
21 \\
19 \\
13 \\
6 \\
3 \\
2\end{array}$ & $\begin{array}{r}28 \cdot 3 \\
67 \cdot 0 \\
146 \cdot 9 \\
243 \cdot 2 \\
311 \cdot 5 \\
364 \cdot 0 \\
364 \cdot 8 \\
382 \cdot 5 \\
412 \cdot 5 \\
387 \cdot 5 \\
410 \cdot 0 \\
382 \cdot 5\end{array}$ & $\begin{array}{r}21 \\
22 \\
37 \\
62 \\
99 \\
115 \\
144 \\
142 \\
162 \\
190 \\
179 \\
227\end{array}$ & $\begin{array}{l}74 \cdot 0 \\
46 \cdot 5 \\
25 \cdot 0 \\
25 \cdot 5 \\
31 \cdot 7 \\
31 \cdot 6 \\
39 \cdot 5 \\
37 \cdot 1 \\
39 \cdot 2 \\
49 \cdot 0 \\
43 \cdot 8 \\
59 \cdot 3\end{array}$ \\
\hline
\end{tabular}

intake and the output recorded in this investigation. The percentage of the intake returned as urine is also shown. Data of this nature are also published by Reusing, table 3. It is not possible to draw any conclusions from a comparison of the two tables for several reasons. The number of the infants varies during the period of observation in table 2 . There are statistical inaccuracies on the first and seventh days in table 3 , and in addition an error in the calculation of the percentage on the seventh day. Apart from his inaccurate use of figures, Reusing's data include infants whose daily water balances are negative or nearly so. For example, one of the six infants has negative water balances of 72 c.c., 41 c.c. and 61 c.c. on the fifth, sixth and seventh days of life respectively. Because of this it is reasonable to doubt whether Reusing's figures can be looked upon as being representative of average normal infants. Nevertheless, Reusing's data have been freely quoted in the paediatric literature.

TABLE 3

\section{AVERAGE DAILY INTAKE AND OUTPUT} (REUSING)

\begin{tabular}{|c|c|c|c|c|c|}
\hline Day & $\begin{array}{c}\text { Number } \\
\text { of } \\
\text { infants }\end{array}$ & $\begin{array}{c}\text { Milk, } \\
\text { c.c. }\end{array}$ & $\begin{array}{l}\text { Number } \\
\text { of } \\
\text { infants }\end{array}$ & $\begin{array}{c}\text { Urine, } \\
\text { c.c. }\end{array}$ & $\begin{array}{l}\text { Per cent. } \\
\text { of intake } \\
\text { returned } \\
\text { as output }\end{array}$ \\
\hline $\begin{array}{ll}1 & \ldots \\
2 & \ldots \\
3 & \ldots \\
4 & \ldots \\
5 & \ldots \\
6 & \ldots \\
7 & \ldots \\
8 & \ldots\end{array}$ & $\begin{array}{l}3 \\
6 \\
6 \\
6 \\
6 \\
6 \\
6 \\
6\end{array}$ & $\begin{array}{r}38 \cdot 3 \\
120 \cdot 8 \\
176 \cdot 6 \\
220 \cdot 0 \\
271 \cdot 5 \\
296 \cdot 6 \\
297 \cdot 0 \\
333 \cdot 0\end{array}$ & $\begin{array}{l}6 \\
6 \\
6 \\
6 \\
6 \\
6 \\
5 \\
6\end{array}$ & $\begin{array}{r}8.4 \\
26.8 \\
40.9 \\
60.8 \\
119.2 \\
148.6 \\
157.0 \\
208.0\end{array}$ & $\begin{array}{l}21 \cdot 8 \\
22 \cdot 2 \\
23 \cdot 1 \\
27 \cdot 6 \\
43 \cdot 9 \\
50 \cdot 0 \\
57 \cdot 6 \\
62 \cdot 5\end{array}$ \\
\hline
\end{tabular}

The frequency of micturition

Fig. 6 illustrates the data collected by means of the electrical signalling device. Martin and Ruge are the only other investigators to publish similar observations. Their data are also shown. The

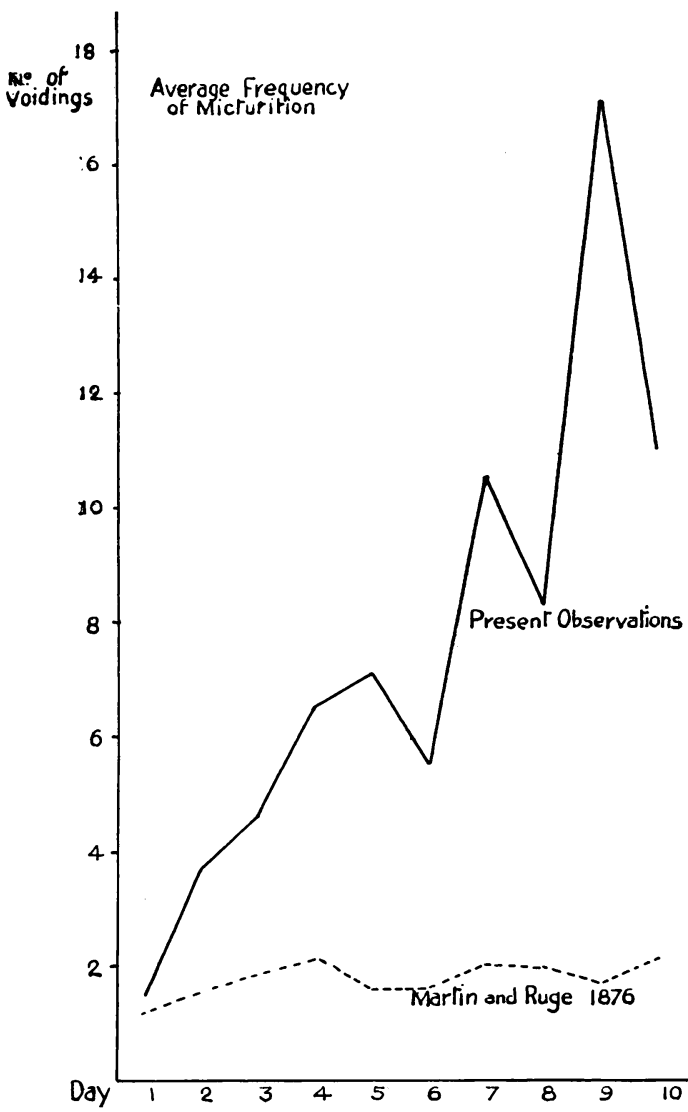

FIG. 6.

divergence between the two series of observations is so great that there is no possibility of reconciling them. It is reasonable to expect that the frequency of micturition should increase with the gradual increase from day to day in the intake of fluid. Engel (1914) has shown that in older infants an increased intake means an increased frequency of micturition. That the new-born infant is no exception to the rule is demonstrated by case No. 7402 .

$\begin{array}{lcccccc}\quad \text { Day } & \ldots & \ldots & 7 & 8 & 9 & \\ \text { Intake } & \ldots & \ldots & 232 \cdot 5 & 277 \cdot 5 & 450 \cdot 0 & \text { c.c. } \\ \text { Output } & \ldots & \ldots & 81 & 82 & 244 \cdot 0 & \text { c.c. } \\ \text { Average volume } & \text { of } & & & & \\ \begin{array}{l}\text { single specimen } \\ \ldots\end{array} & 10 \cdot 12 & 11 \cdot 71 & 9 \cdot 76 \text { c.c. } \\ \text { Frequency } & \ldots & \ldots & 8 & 7 & 25 & \text { times }\end{array}$

The data given by Martin and Ruge are based partly on direct observation of micturition, and partly on inference. This, no doubt, is the explanation of the discrepancy disclosed by the graph.

The volume of urine passed at one voiding

The amount of urine passed at each voiding varies within wide limits. This is shown in table 4 . The scatter of the observations is illustrated in fig. 7 .

\begin{tabular}{ccrrrrr}
\multicolumn{8}{c}{ TABLE 4} \\
Day & $\ldots$ & 1 & 2 & 3 & 4 & 5 \\
Maximum vol., c.c. & $\ldots$ & $30 \cdot 0$ & $34 \cdot 0$ & $34 \cdot 0$ & $38 \cdot 0$ & $32 \cdot 0$ \\
Minimum vol., c.c. & $\ldots$ & $1 \cdot 5$ & $1 \cdot 0$ & $2 \cdot 0$ & $3 \cdot 5$ & $2 \cdot 0$ \\
Average vol., c.c. & $\ldots$ & $9 \cdot 2$ & $10 \cdot 2$ & $12 \cdot 5$ & $13 \cdot 5$ & $11 \cdot 7$
\end{tabular}



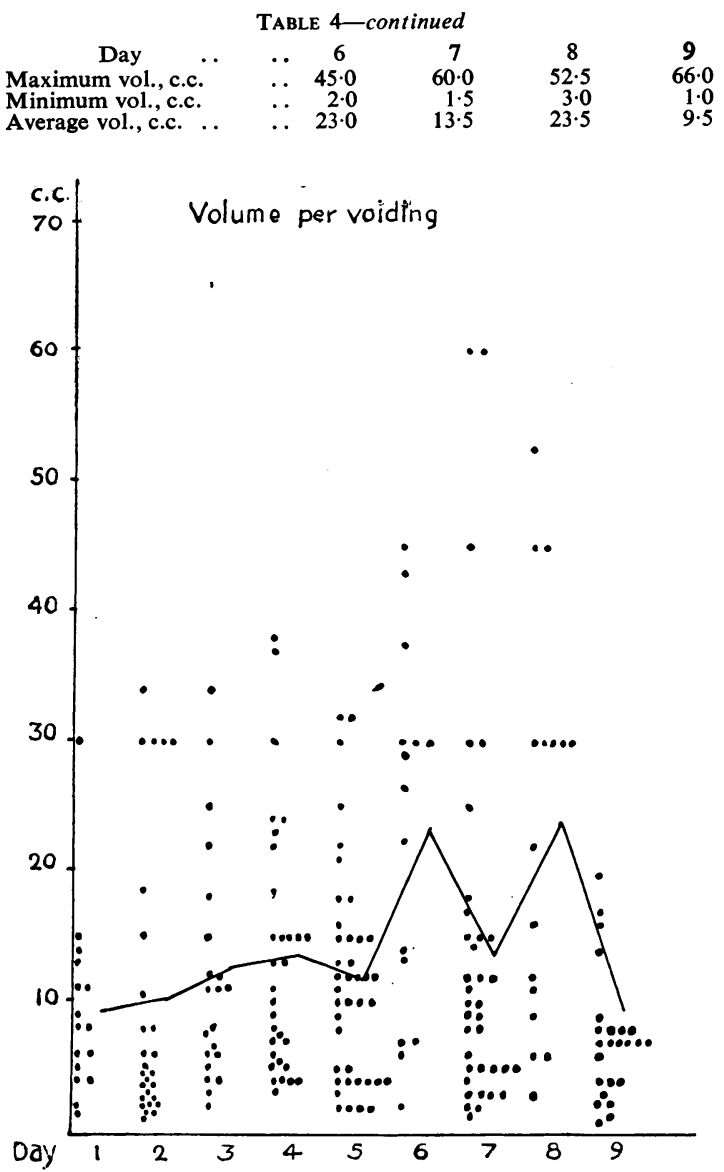

FIG. 7.

The average figure of $9 \cdot 2$ c.c. for the first day of life compares very favourably with the figure of $9 \cdot 6$ c.c. given by Martin and Ruge as the average volume of the first specimen of urine to be passed post-natally. Comparison is also not unfavourable with the figures of Dohrn (1867), Reusing (1895), Martin, Ruge and Biedermann (1875), and Parrot and Robin (1876). See table 5.

After the first five days the figures tend to become more erratic. This may be due to the observations being made on too small a number of infants and also to the greatly varying factor introduced at this time by the establishment of lactation. The wide range between the minimum and maximum volumes of urine passed at one voiding may be observed in one infant.

Example: Infant No. 9749. 2nd Day.

\begin{tabular}{cclc} 
Time & $\begin{array}{c}\text { Urine, } \\
\text { c.c. }\end{array}$ & \multicolumn{1}{c}{ Time } & $\begin{array}{c}\text { Urine, } \\
\text { c.c. }\end{array}$ \\
4.0 a.m. & 30 & 1.15 p.m. & 34 \\
7.10, & 7.5 & 4.0, & 26 \\
9.30 , & 30 & $4.30 .$, & 12 \\
11.35, & 1 & &
\end{tabular}

Once lactation is fully established and the intake is sufficient to meet normal physiological requirements, the volume of urine passed at one voiding may be larger.
TABLE 5

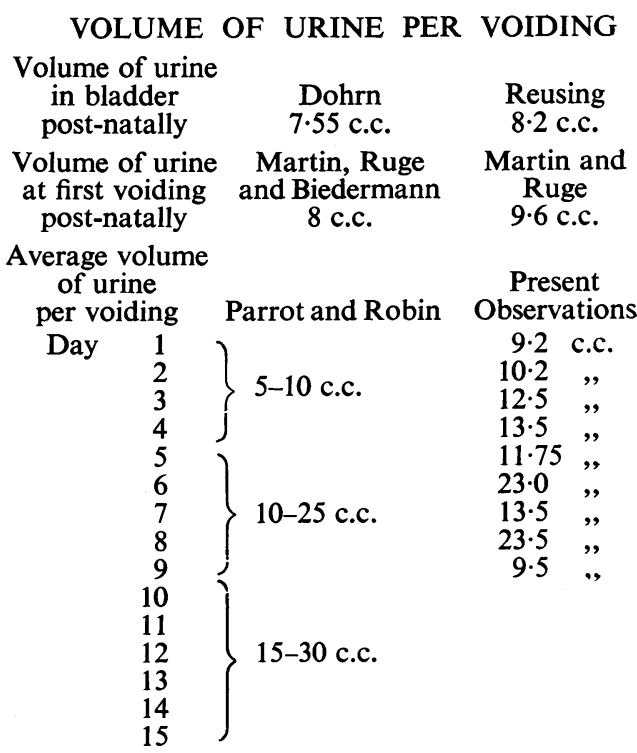

Example: Infant No. 389. 6th Day.

$\begin{array}{cccc}\text { Time } & \text { Urine, c.c. } & \text { Time } & \text { Urine, c.c. } \\ 4.0 \text { p.m. } & 45 \mathrm{M} & 1.0 \text { a.m. } & 30 \mathrm{~A} \\ 7.50 \%, & 30 \mathrm{~A} & 8.30 \%, & 22.5 \mathrm{M} \\ 11.0 \% & 30 \mathrm{~A} & 11.0,, & 37.5 \mathrm{~A}\end{array}$

Incidentally, this record shows how an attempt can be made to check the efficiency of the signalling apparatus and also to some extent estimate the capacity of the bladder. Observations marked A were made with the electrical apparatus, whereas those marked $M$ denote the volume of urine passed at a nursing period when the infant was in its mother's arms. On these occasions the electrical apparatus is disconnected and is replaced by a testtube. These high and relatively infrequent passages of urine are not to be looked upon as invariable. They may be contrasted with the following case.

Example: Infant No. 7675. 5th Day.

$\begin{array}{cccc}\text { Time } & \text { Urine, c.c. } & \text { Time } & \text { Urine, c.c. } \\ 2.30 \text { p.m. } & 8 \& 9 & 2.20 \mathrm{a} . \mathrm{m} . & 10 \\ 4.0 \text { ", } & 4 & 3.15, & 12 \\ 5.45, " & 13 & 4.0 \%, & 10 \\ 7.45, " & 12 & 7.30, & 18 \\ 9.0 \text { ", } & 12 & 8.20, & 12 \\ 10.15, " & 13 & 11.20, & 32 \\ 1.0 \text { a.m. } & 15 & 11.45, & 10 \\ 1.30, " & 4 & 1.45 \mathrm{p.m} . & 10\end{array}$

Broadly speaking, the data show a slow and gradual rise in the volume of urine voided on each occasion as the days pass, but a much more rapid rise in the frequency of micturition.

\section{The specific gravity}

Owing to the smallness of the volumes of the urine it is not always possible to determine the specific gravity by the urinometer. Alternative methods are, either to use a Sprengle's tube or to follow the method of Kirkpatrick and Kling (1926). The present observations were made with a urino- 


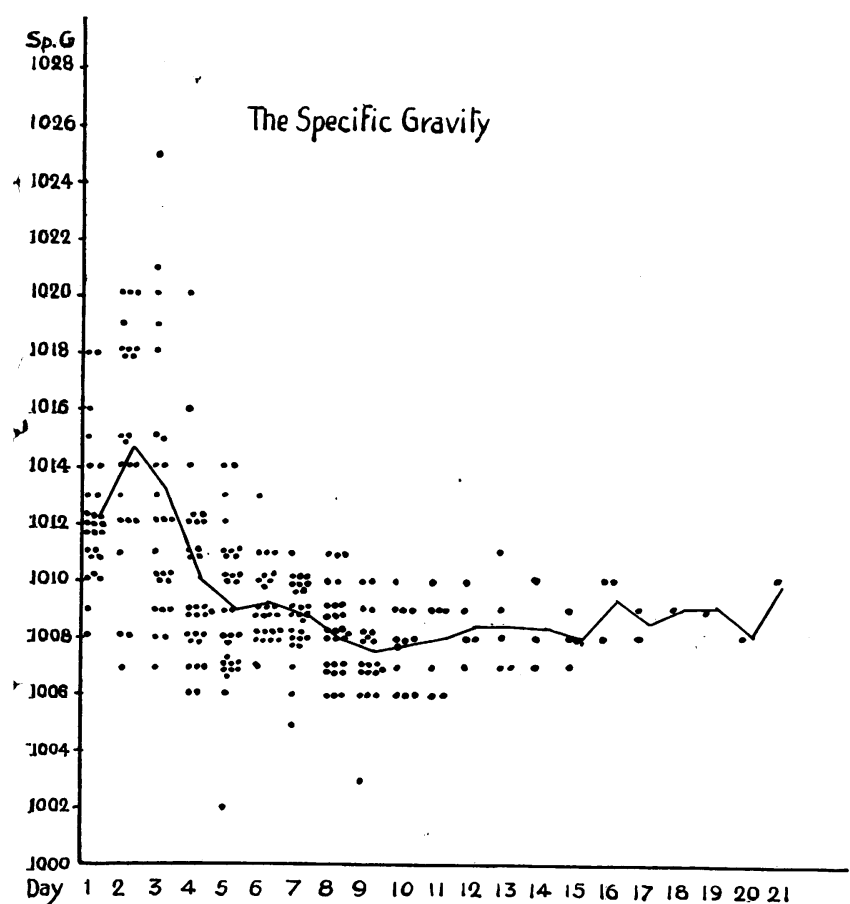

FIG. 8.

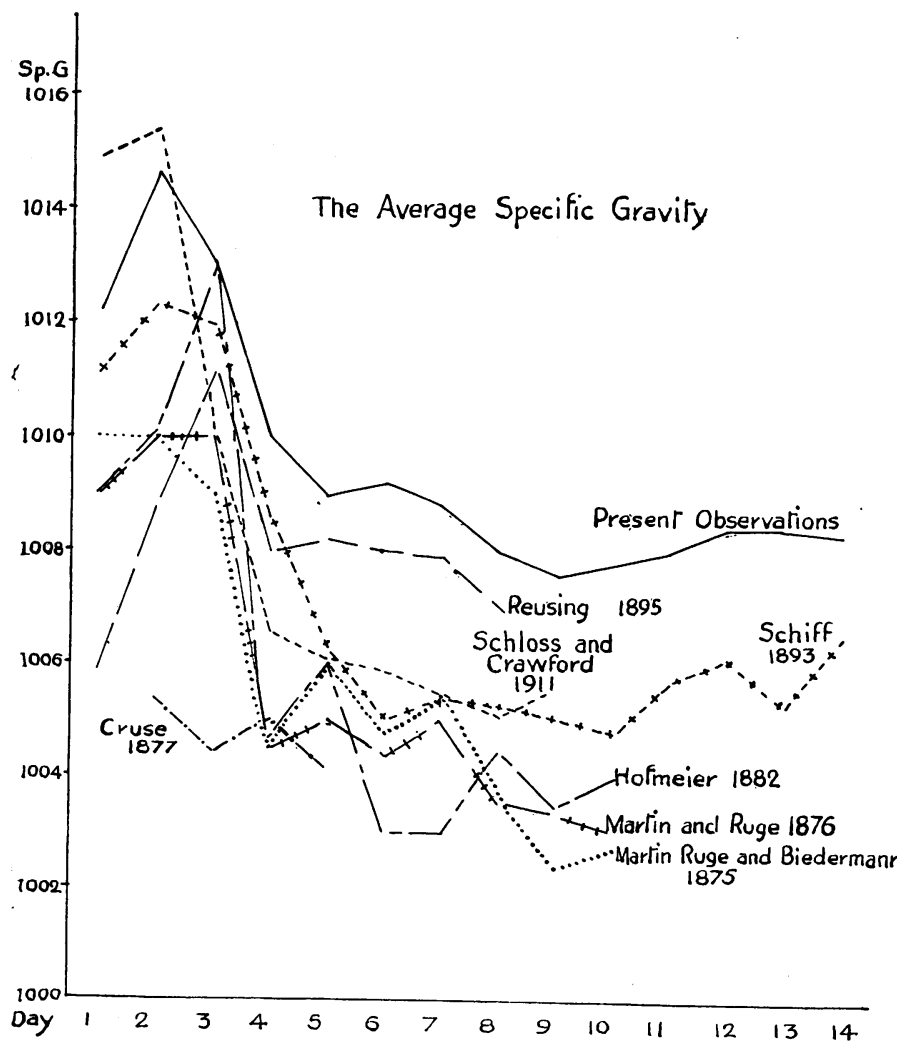

FIG. 9.

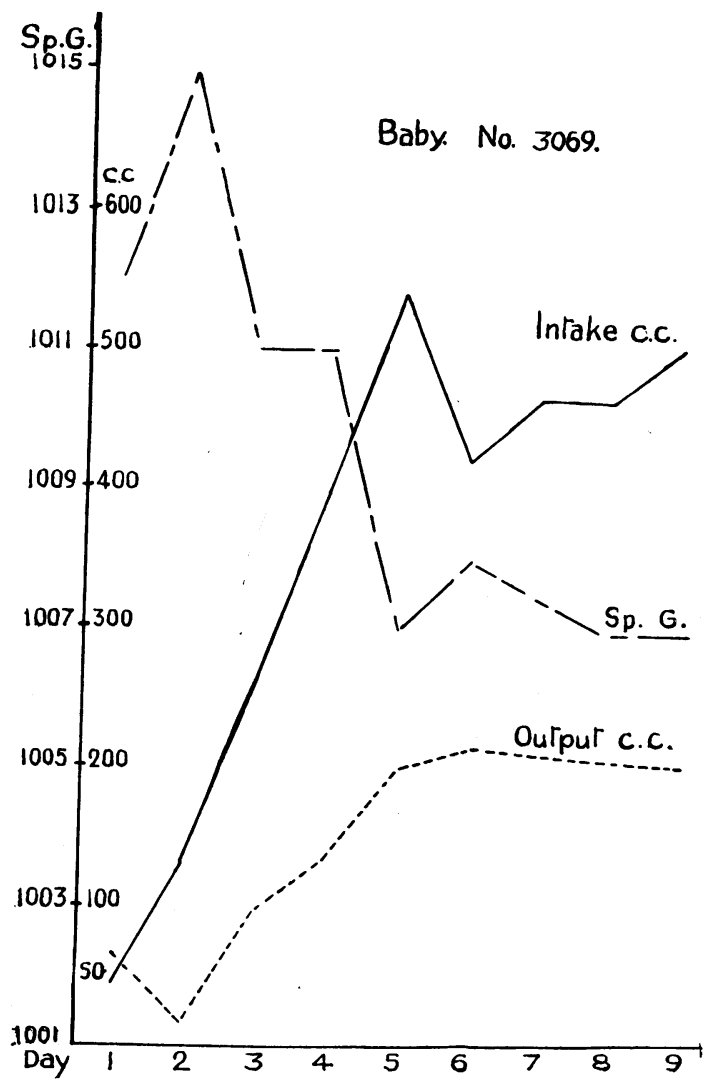

FIG. 10.

meter when possible and by direct weighing of the small specimens. The use of the urinometer to take the specific gravity of a specimen consisting of the pooled but varying volumes passed by different infants on the same day of life was practiced by Martin and Ruge (1876), Michel and Budin (1897), and Moore (1917). This method cannot give an accurate result. Schiff and Reusing were unable to give the specific gravity of all their specimens of urine because they relied on the urinometer.

The data obtained in the present investigation are shown in fig. 8. Following an initial rise in the first and second days there is a steady decline until the eighth day, when the specific gravity becomes more stabilized. This coincides with the time when the daily intake at the breast becomes more stable. The form of the graph is similar though not identical with that of Schloss and Crawford, Schiff, Hofmeier, Martin and Ruge, Martin, Ruge and Biedermann, and Reusing (fig. 9). The maximum figure reached is 1025 on the third day. This increase in the specific gravity of the urine during the first forty-eight hours of life is probably related to the infant's need to conserve the body water reserve during this period. The relationship between the increasing intake and the increasing output on the one hand and the fall in the specific 
gravity of the urine on the other is well demonstrated in fig. 10 .

\section{The $p \mathrm{H}$ of the urine}

In estimating the hydrogen ion concentration of the urine the B.D.H. capillator method was used and the specimens were collected under a layer of toluol. The data collected are presented in fig. 11. It is observed that the daily average $p \mathrm{H}$ of the urine passes steadily from a very definitely acid concentration towards neutrality. This trend is not confined to the daily average figure but is observed in individual infants as the following examples demonstrate.

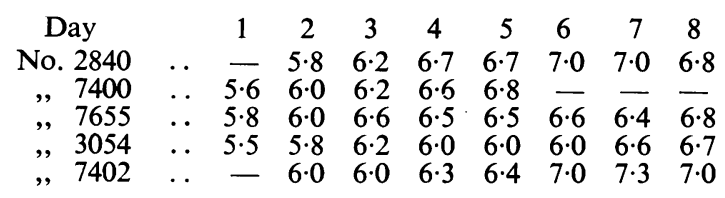

The high $p \mathrm{H}$ observations made on the urine passed in the first few days of life are probably related to the acidotic state of the new-born infant (Seham, 1919). This is a matter of some clinical importance. It is well recognized that the new-born infant has an imperfectly developed defence mechanism against bacterial invasions. Unlike the adult it is peculiarly liable to succumb to a B. coli infection. The risk of a urinary infection is contributed to in some measure by the fact that the optimum $p \mathrm{H}$ for the growth of $\mathrm{B}$. coli lies between $p \mathrm{H} 6$ and $p \mathrm{H} 7$ (Wilson, 1929). The high $p \mathrm{H}$ of the urine in the first two days of life is associated with a relatively low fluid intake, and therefore it is to some extent due to the need to conserve the body water reserve

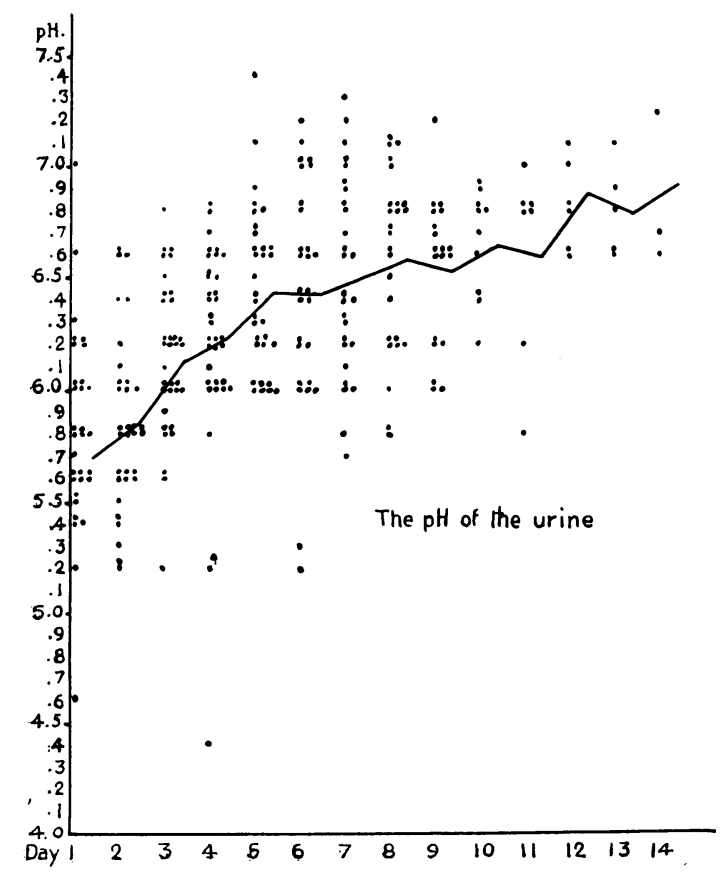

FIG. 11. at this time. It is probable that here is an indication that it is desirable to supply the new-born infant with sterile water.

\section{The chloride content}

There are few publications which deal with the chloride content of the urine in the new-born period.

Picard (1856) is the earliest investigator and he is followed by Hecker (1857). Their work, like that of Parrot and Robin (1876) and Martin and Ruge (1876), is of no more than historic value. The data published by Cruse (1877) are not applicable to the average new-born infant since his observations were made on infants which were wet nursed. The only other publication is that of Schiff (1893).

The present investigation shows that there is a steady fall in the concentration of chloride during the first four days after birth. This is followed by an increase in the concentration during the next three or four days, after which a steady decline is again apparent. Fig. 12 shows that Schiff's data are very similar. The increase in the concentration of the chlorides from the fifth to the eighth days is, in all probability, due to more than one factor. An examination of the chloride concentration of colostrum and early breast milk shows that there is a steady decline from the first day onwards. This is shown in fig. 13. Nevertheless, the total chloride output increases steadily from the fourth to the

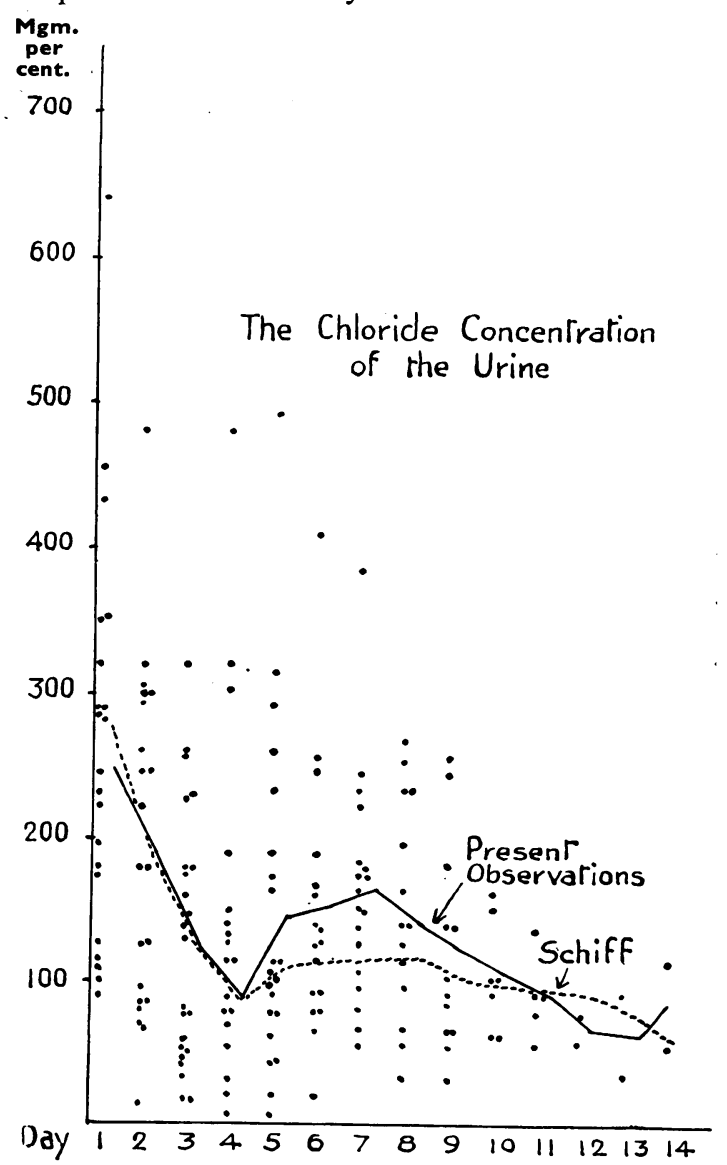

FIG. 12. 

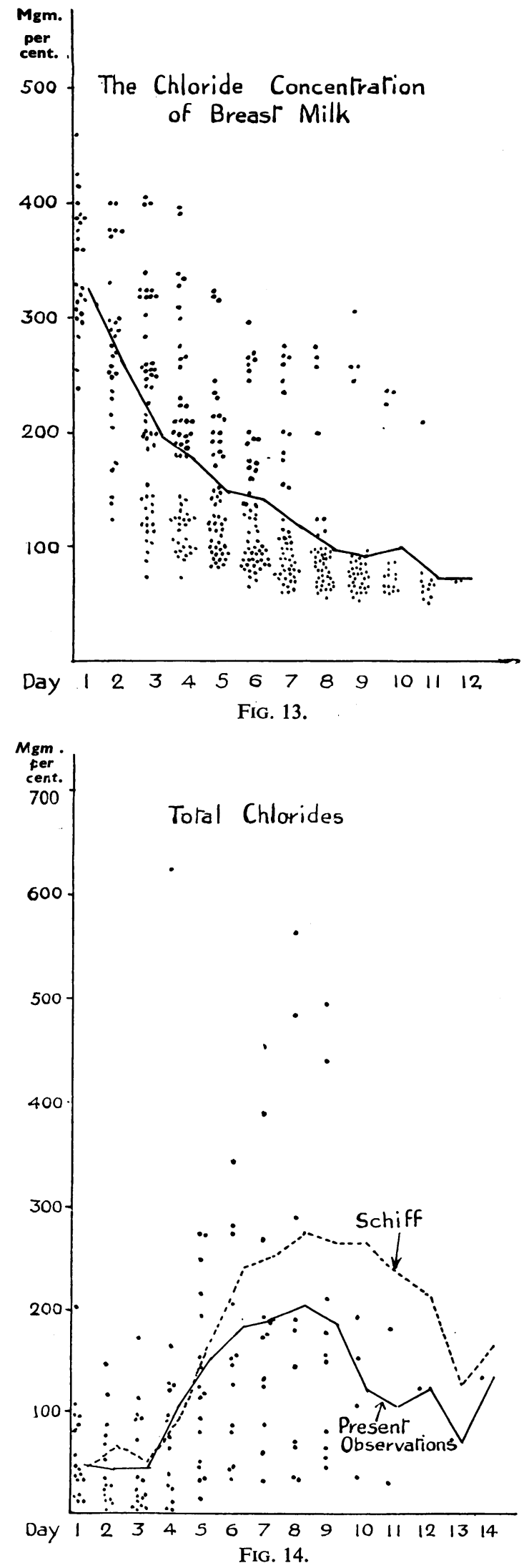

ninth day, a consequence no doubt, of the larger feeds obtained at the breast. During the first three or four days of life it is certain that there is a considerable depletion of the body water reserve and that this reserve is re-established at the earliest opportunity. It is probable that this is the explanation of the increase of the chloride concentration from the fifth to the eighth days, and its subsequent decline.

Here let it be said that publications dealing with the chloride content of colostrum and early breast milk are rare and there is no authoritative work published on chloride utilization by the new-born infant. The total daily chloride output varies considerably from infant to infant. It is probable that the time of the onset of lactation and the volume of the intake at the breast are the most important determining factors. These are variable. The total daily chloride output is shown in fig. 14. The graph is similar to but not identical with that representing the work of Schiff.

\section{The urea content}

Like all other observations on the urine in the new-born period the urea concentration varies widely, and especially so during the first four or five days. This is illustrated in fig. 15. The graph shows an increase in the urea concentration from $689 \mathrm{mgm}$. to $827 \mathrm{mgm}$. per cent. in the first twenty-four hours. This is followed by a steady decline to $156 \mathrm{mgm}$. per cent. on the twelfth day. The graph is similar to though not identical with those representing the work of Schiff and Reusing (fig. 16). It is observed that the highest concentrations occur during the first five days. The low volume of the fluid intake during this period and the consequent need to conserve the body water reserve are no doubt adequate explanation of this. It is interesting to note, and it is not without significance, that a similar trend in the urea nitrogen concentration of the blood in the new-born infant is reported by Schultz and Pettibone (1915), Sedgwick and Ziegler (1920) and Lucas et alia (1921) (fig. 17).

The total urea output varies considerably throughout the whole period. Reference to fig. 18 shows a variation of as much as $400 \mathrm{mgm}$. in the first twenty-four hours. This range is exceeded on every subsequent day, the difference on the ninth day being over $700 \mathrm{mgm}$. There are many factors which will influence the total urea output in this age reriod. The protein content of the colostrum and early breast milk is itself an exceedingly variable factor, and without a fuller knowledge of the protein intake it is idle to speculate upon or discuss the subject. Ranges of output amounting to more than double the above figures are published by Schiff (1893) and Reusing (1895). The daily urea output is not only wide in its range, it may also vary greatly from day to day in the same infant. For example:-

\footnotetext{
$\begin{array}{lllllllll}\text { Day } & \text {.. } & 1 & 2 & 3 & 4 & 5 & 6 & 7\end{array}$ $\begin{array}{cccccccc}7655 . \quad \text { Urea, } & 222.6 & 542.75 & 127.4 & 669 \cdot 6 & 1170 \cdot 4 & 854.9 & 333 \cdot 7\end{array}$
} 


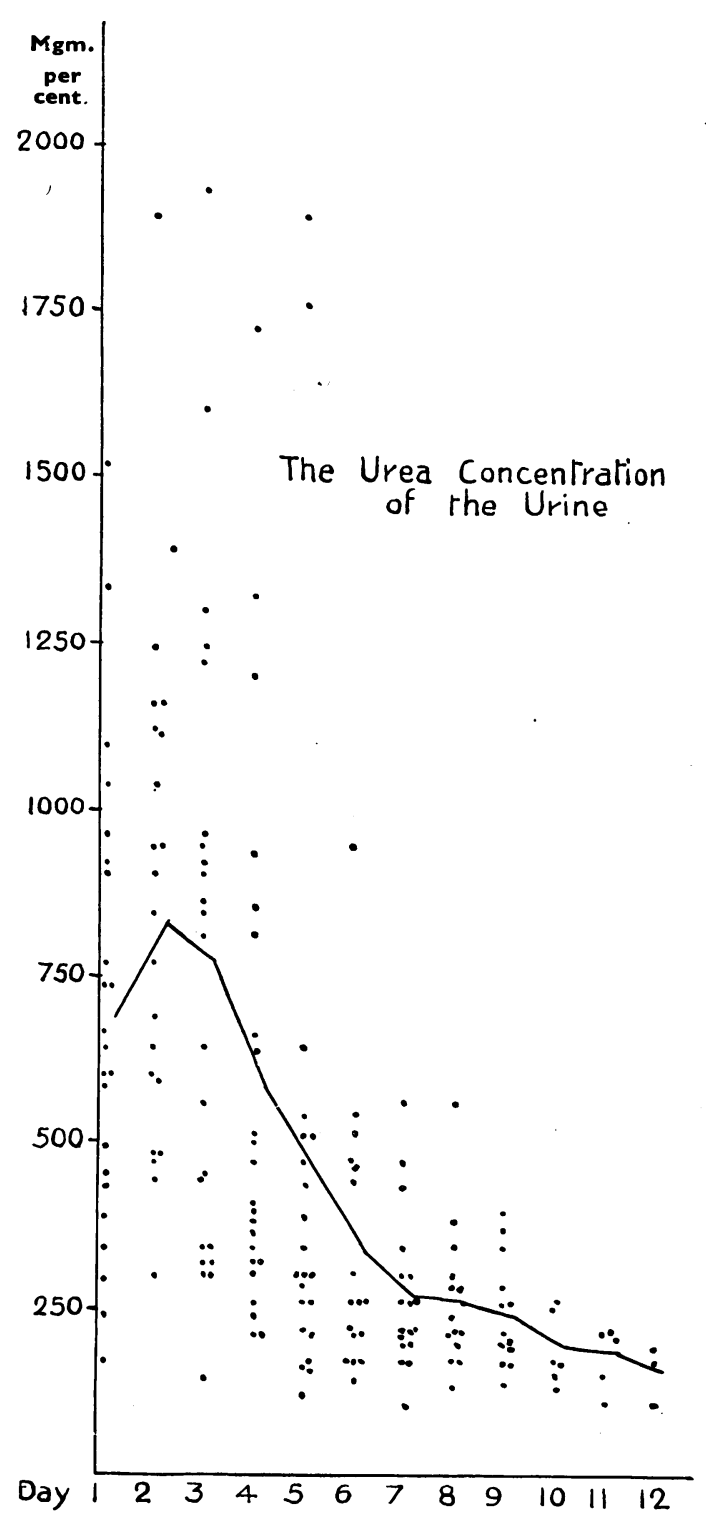

FIG. 15.

Similar variations are recorded by Schiff and Reusing.

\section{Commentary}

These observations were made upon breast-fed infants of average weight and in whom there was no clinical evidence of abnormality. No case of dehydration fever is included. Neither is there any case of jaundice excepting a very transient physiological one. It follows that the results obtained are very much the reflection of the onset of lactation and the establishment of breast feeding. This physiological phenomenon varies greatly in different mothers and is not infrequently beset with many difficulties. Some of these are physiological in origin as, for example, excessive engorgement of the breasts; others arise from defects of structure, for instance, the retracted nipple. Yet others, like

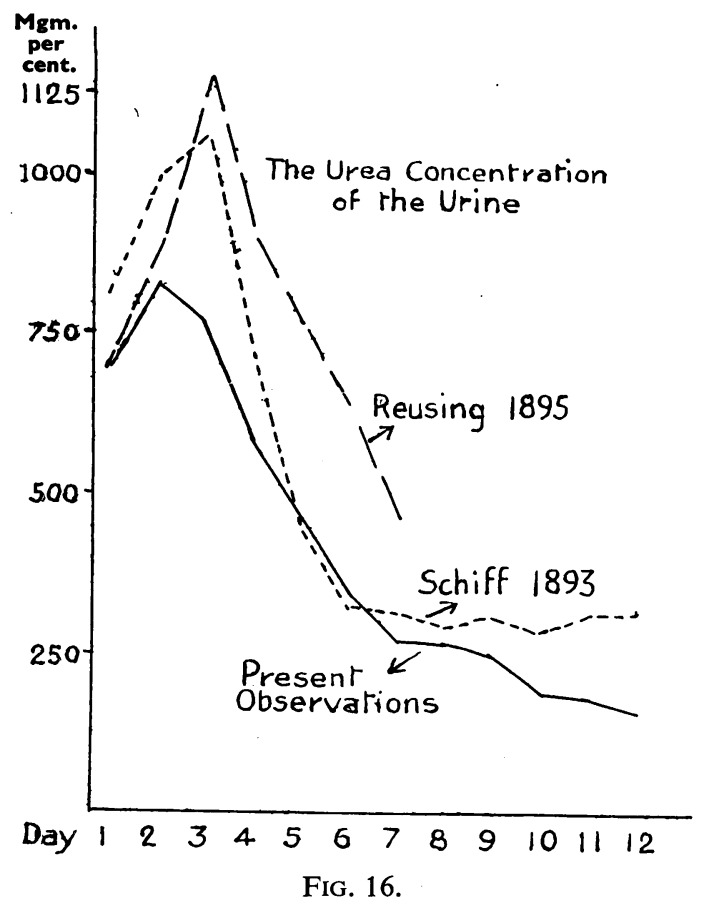

FIG. 16.

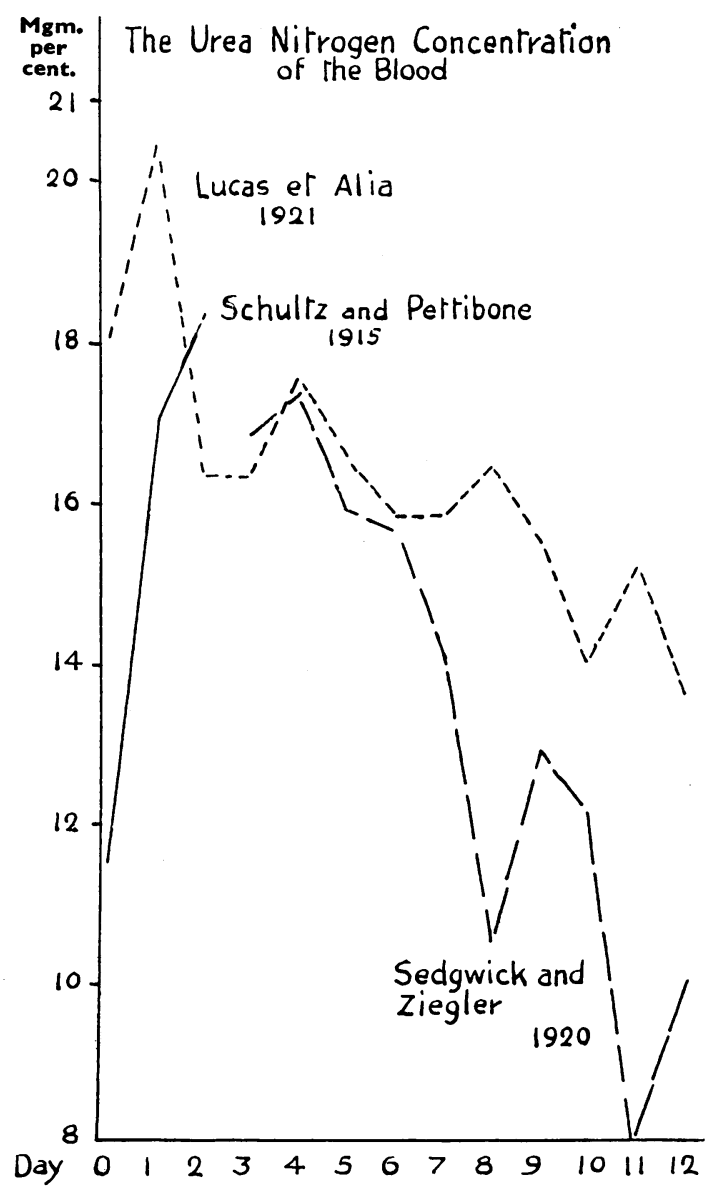

FIG. 17. 


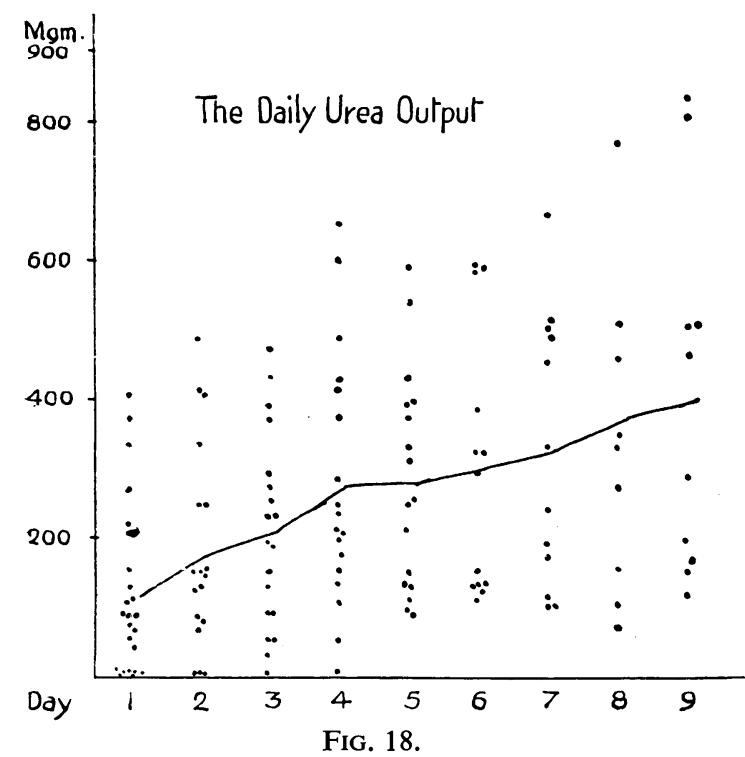

fissured nipples and mastitis, are frankly pathological. With such a capricious source of nutrition it is not to be wondered at that in some new-born infants there are wide fluctuations in the volume of the urine and the output of urea and chloride from day to day. Nevertheless, the results obtained show that in the first days of life the volume of the urine gradually increases as does the frequency of micturition. The output of urea rises each day, but no parallel course is seen in the chloride output. The specific gravity falls while the $\mathrm{pH}$ travels steadily towards alkalinity.

\section{REFERENCES}

Camerer, W. (1896a). Württemb. Korresp. Bl., 46, No. 11 . (1896b). Jb. Paediat., 7, 90.

Cruse, P. (1877). Jb. Kinderheilk, 11, 393-432.

Dohrn, Prof. (1867). Mschr. Geburtsh. Frauenkrankh., 29, 105.

Engel, S. (1914). Dtsch. med. Wschr., 40, 1960.

Hecker, C. (1857). Virchows Arch., 11, 217.

Hofmeier, M. (1882). Ibid., 89, 493.

- (1878). Zbl. Gynaek., Nr. 18, 409.

(1879). Z. Geburtsh. Gynäk., 4, 114.

Kirkpatrick, J., and Kling, D. H. (1926). J. Amer. med. Ass., 87, 487.

Lucas, W. P., Dearing, B. F., Hoobler, H. R., Cox, A., Jones, M. R., and Smyth, F. S. (1921). Amer. J. Dis. Child., 22, 525.

Martin, A., and Ruge, C. (1876). Z. Geburtsh. Frauenkrankh., 1, 273.

-., - , and Biedermann. R. (1875). Zbl. med. Wiss., 24, 387.

Michel, C., and Budin, P. (1897). L'Obstetrique, Paris, 2, 97-115; 211-229.

Moore, C. U. (1917). Amer. J. Dis. Child., 13, 15.

Parrot, J., and Robin, A. (1876). Arch. gén. Méd., 1, $129,309$.

Picard, (1856). Quoted by Cruse.

Reusing, H. (1895). Z. Geburtsh. Gynäk., 33, 36.

Schiff, E. (1892). Jb. Kinderheilk, 34, 159, 459.

- (1893). Ibid., 35, 21.

Schloss, O. M., and Crawford, J. L. (1911). Amer. J. Dis. Child., 1, 203.

Schultz, F. W., and Pettibone, C. J. V. (1915). Ibid., 10, 206.

Sedgwick, J. P., and Ziegler, M. R. (1920). Ibid., 19, 429.

Seham, M. (1919). Ibid., 18, 42.

Wilson, W. J. (1929). A System of Bacteriology. Medical Research Council, 4, 269. 